\title{
Family-based collaborative ecoliteracy model for sustainable city
}

\section{Model ekoliterasi kolaboratif berbasis keluarga untuk kota berkelanjutan}

\author{
$\underline{\text { Sudar Itafarida }}^{1}$, Eduardus Bimo Aksono Herupradoto ${ }^{2}$, Usma Nur Dian Rosyidah ${ }^{1}$, \\ \& Erlita Rusnaningtias ${ }^{1}$ \\ ${ }^{1}$ Department of English Literature, Faculty of Humanities, Universitas Airlangga \\ ${ }^{2}$ Department of Veterinary Basic Medicine, Faculty of Veterinary, Universtas Airlangga \\ Address: ' Jalan Dharmawangsa Dalam, Surabaya, East Java 60286 \\ ${ }^{2}$ Kampus C, Mulyorejo, Surabaya, East Java 60115 \\ E-mail: sudaritafarida@gmail.com
}

\begin{abstract}
The process of adaptation and adoption of modern values by multicultural urban communities raises various problems, especially those related to the environment. In Surabaya and Sidoarjo, even though the Surabaya City Government and the Regional Government of Sidoarjo have carried out various environmental programs, the demands of a fast and practical modern lifestyle create egocentric and anthropocentric attitudes. Urban communities must take on the continuous socialization of ecocentric behavior that adopts modern values but must also maintain the value of local wisdom to support the realization of sustainable city. The familybased collaborative ecoliteracy model is needed as a strategy to develop green living cultural values that can be practiced by all levels of society in various regions with different characteristics in both cities. This model directly touches the family as the main place to cultivate ecocentric mindset and behavior. Another consideration is that there is few government policies related to environment that directly target the family. This study illustrates how the family-based collaborative ecoliteracy model was applied to families in Surabaya and Sidoarjo and explains how the model has moved the attitudes and behavior of these families to those in line with ecocentric principles. By using a qualitative-descriptive approach, this model was applied to 16 families selected according to participant criteria. The subsequent changes in behavior were observed over a period of six months. The results of the application of the model show that each individual in the family collaborates and strengthens due to collective competence, which is an ecocentric value. Based on the orientation of green living values in eleven sustainable urban components, it can be concluded that almost all green city programs carried out by the government are intended to realize Surabaya and Sidoarjo as sustainable cities.
\end{abstract}

Keywords: green living; collective competence; family-based collaborative ecoliteracy model; sustainable city

\begin{abstract}
Abstrak
Proses adaptasi dan adopsi nilai modern oleh masyarakat urban yang multikultural menimbulkan berbagai persoalan, terutama yang terkait dengan lingkungan hidup. Di Surabaya dan Sidoarjo, meskipun pemerintah kota dan daerah telah melakukan berbagai program lingkungan hidup, adanya tuntutan gaya hidup modern yang praktis dan cepat membuat masyarakat cenderung menjadi lebih egosentris dan antroposentris. Masyarakat urban perlu memperoleh kampanye dan sosialisasi berkesinambungan mengenai perilaku ekosentris yang mengadopsi nilai-nilaimodern namun tetap mempertahankan nilai kearifan lokal untukmendukung terwujudnya kota yang berkelanjutan. Model ekoliterasi kolaboratif berbasis keluarga diperlukan sebagai strategi untuk mengembangkan nilai budaya hidup hijau yang dapat dipraktikkan oleh semua lapisan masyarakat di berbagai karakteristik wilayah di kedua kota. Model ini langsung menyentuh keluarga sebagai tempat utama untuk membudayakan pola pikir dan perilaku ekosentris. Pertimbangan lain adalah belum banyak kebijakan pemerintah terkait lingkungan hidup yang secara langsung menyasar keluarga. Penelitian ini menggambarkan bagaimana model ekoliterasi kolaboratif berbasis keluarga diterapkan pada keluarga-keluarga yang ada di Surabaya dan Sidoarjo serta menjelaskan bagaimana model tersebut bisa mengubah sikap dan perilaku keluarga-keluarga tersebut menjadi lebih ekosentris. Dengan menggunakan pendekatan deskriptif-kualitatif, model ini diterapkan pada 16 keluarga yang dipilih sesuai kriteria partisipan dan yang selanjutnya diamati perubahan perilakunya dalam kurun waktu enam bulan. Hasil penerapan model menunjukkan bahwa setiap individu dalam keluarga saling bekerjasama dan menguatkan karena telah tercapai kompetensi kolektif, yakni menjadi lebih ekosentris. Berdasarkan orientasi nilai budaya green living pada kesebelas komponen kota hijau
\end{abstract}


yang berkelanjutan tersebut, dapat disimpulkan bahwa pada intinya semua program kota hijau yang dilakukan pemerintah tersebut ditujukan untuk mewujudkan Surabaya maupun Sidoarjo sebagai kota berkelanjutan.

Kata kunci: green living; kompetensi kolektif; model collaborative ecoliteracy berbasis keluarga; kota berkelanjutan

\section{Introduction}

A city is one of important tools in a development program due to its incresing number of inhabitant annually. In the thirty years ahead, it is expected that the majority of people in a country will reside in the city. Places that have been categorized as rural will be urbanized. Urban stakeholders should prepare to face this rapid urbanization particularly pertaining to issues of urban settlement and the sustainability of urban development.

The United Nation (UN) has warned the increasing urbanization process which occured globally especially in turn of the 2000. According to the UN Habitat Agenda, in order to prevent the spread of slum area due to the massive urbanization, the UN has introduced the Millenium Develeopment Goals (MDGs) targetting 'City without a slum' as the main priority. Furthermore, after 2015, The UN also offers the New Urban Agenda focusing on how to address the rapid urbanization through a sustanable development plans. This step becomes a starting point of changing paradigm of development in many countries. Prior to the 2015 the development plan was centralized at national level, yet it has rececntly been distributed to the local-regional or city level. Countries have followed up this plan by actively participating in the UN Habitat meeting. As the concequence of the appointment of Surabaya as a meeting venue of the 2016 III UN Habitat, the city of Surabaya also participated in the PrepCom, a conference preceding the 2016 III UN Habitat held in Equador. This conceference discussed everything required to the ideal future urban development agenda in the 20 years ahead. The result of the PrepCom, which was participated by the city mayors throughtout the world, became a new concencuss called New Urban Agenda announced in Qoiro, Equador in October 2016.

The consideration of appointing Surabaya to become the venue of the 2016 III UN Habitat Meeting lies on the succesful record by the municipal of Surabaya in delivering good governance program promoting sustainable development, especially the famous tagline Surabaya Green and Clean in early 2000. In so doing, the municipal always invites communities and the smallest local government (kelurahan) to participate in empowering society. Although the neighbouring regencies duplicate this strategy, they are less effective due to the different local context and step by step approach in delivering program as it is conducted through the Green and Clean program.

Among the so many programs implemented in the city of Surabaya as in our previous research, there is found an inconsistency between the plan and its implementation in society, especially in individual behaviour. Therefore, it requires advanced approach through which the urban sustainable development can be delivered into small-scale unit of development that are individual and familiy level. Indeed, the family-based models are considerably more appropriate approach toward the urban development for all.

The family-based model is opted by considering the family function as the place of social value transmission. Schwartz (1992) defines value as a social goal that varies in term of its interest, functioning as a blue print for individual as well as community. Based on that definition, there are three main characterics of the value. Firtsly, the value reflects a will toward an end goal. Secondly, the value always apperas in an abstract form which is beyond any kind of situation. Thirdly, the value functions as a blueprint of behaviour, mankind, or phenomenon. And finally, the value is always arranged as a priority system.

Relating to the value of green living, Merchant (1990) distinguishes the three environmental-oriented values. It consists of 1) egocentric which is based on individual interest; 2) anthropocentric which stresses on social virtue; and 3) ecocentric which underscores the essential value of ecosystem. The moving from egocentric toward ecocentric point of view in both individual and communal level is the goal of the family-based eco-literacy model. 
The family-based eco-literacy model is initially contructed based on Itafarida et al. research finding in 2014-2015. The finding consists of 1) the shifting value from local wisdom toward modern source of value in the everyday life; 2 ) the practice and the reproduced meaning of green living partially by society; 3 ) the inconsistency of the green living implementation in the level of family and society. This finding, then, is restudied by refering to the municipal policies that actually have not addressed the family. For that goal, this literacy model is set to be based on family and will be started from individual, family and society.

The term ecological literacy or eco-literacy was first coined by Orr and Capra in the 1990s and practiced in the context of education. According to both, eco-literacy is a way of thinking about the world in terms of natural and human systems that are interdependent, including consideration of the consequences of human actions and interactions in natural contexts. Orr and Capra say there are five main aspects of eco-literacy, namely 1) principles of living systems, 2) designs inspired by nature, 3) systems thinking, 4) ecological paradigms and transitions to sustainability, 5) collaboration, community development, and citizenship.

As a complement, the critics agreed that the framework of eco-literacy does not only stop at the main aspects of knowledge about how to overcome environmental problems through values and actions, but also includes cognitive skills, especially "scientific inquiry" and "ecological thinking" for decision making. (Mc Bride et al. 2013). To be able to make decisions, Berkowitz (1997) and Berkowitz et al. (2005) write down aspects that must be fulfilled, namely knowledge about ecology, socio-politics and environmental issues with cognitive skills and environmentally responsible behavior (ERB). Ecologically-literated individuals are able to understand causal relationships that exist and occur in the environment. When eco-literacy has become a thinking system, an individual who has ecological literacy will, as written:

“... have a clear perception and understanding of a system's dynamics and fixtures, as well as its past and alternate future trajectories. He or she understands the complexity of studied objects and phenomena, allowing for more enlightened decision-making." (McBride et al. 2013).

Surabaya was chosen because of its visions and missions to become an environmentally-insightful city evidenced by various programs and policies for environmental preservation. While the neighbouring regency, Sidoarjo, was also nominated yet its policy implementation in the field had not been as massive as Surabaya. In addition, Surabaya and Sidoarjo have similar social characteristics that were urbanized and multiculture. Even so, the people in these cities still relatively had strong emphatic and famial values among each others. This familial value is a capital that can be collaborated since the family level. Every family member in these two cities helps each other to become eco-literacy. Compared to other roles, the role of the family for sustainability is actually vital. As a community unit, members of a family will internalize the value and bahaviour of (relatively) homogen sustainable concept. Leger \& Pruneau (2011:2-11) coined as "general competencies, general biosphere values, and collaborative family dynamics".

\section{Research Method}

This study is a descriptive qualitative research using cultural ecological ethnographic approach. This approach was used because this study discussed three aspects, namely individual knowledge of social values and the culture of green life which became a phenomenon in the lives of urban people, mindset and individual behavior of these cultural values, and various cultural forms related to cultural values of use.

The three stages of the Cultural Ecological conceptual procedure according to Steward (1993) that are carried out in this study consist of 1) analyzing the interrelationships between material culture and the environment, 2) analyzing related behavioral patterns with the technology used, and 3) analyzing how these behavioral patterns affect other aspects of culture, in this case an effort to realize sustainable city. 
The three stages of Cultural Ecology are analyzed by using eco-critique theory in the framework of sustainable city. The eco-critique main focus is to criticize the unequal relationship between humans and nature. The eco-critique exponents explained two ethical values related to human relations with nature, namely anthropocentric and ecocentric. Anthropocentrism assumes or views that the interests of humans are of higher priority than those of nonhumans (Buell 2005:134). According to this perspective, human interests and activities must take precedence and priority over others. Conversely, ecocentrism holds that the interest of the ecosphere must override that of the interest of individual species (Buell 2005:137).

This anthropocentric point of view is believed to be a source of disaster for humans as well as ecology. Therefore, eco-critique offers an ecocentric view that is much friendly with nature. The ecocritique offers a dialogical relationship with nature, placing the concept of nurturing between nature and culture. This nurture position then becomes a justification for "culture as a dynamic continuity" (Coupe 2000:230). Along with the anthropocentric orientation of urban development, awareness as part of the continuity of cultural dynamism is raised by nurturing relations. This awareness is in line with Elder's statement that "to live in an urban world, cut off from tradition and nature, is to experience a life-threatening wasteland" (Coupe 2000:232). To avoid these threats, individuals must have an awareness that "the cycles of human life only achieve health and wholeness in a community which also includes the earth's non-human processes and entities" (Coupe 2000:232-233).

The concept of sustainability of the city defines the city that enables all citizens to meet their own needs and enhance their well-being, without degrading the natural world of other people, now or in the future (Girardet 2004:6). The concept of sustainable city carried by Girardet focuses on the environment and the health and well-being of its residents. Regarding the sustainability mission, a city can be categorized as green city if all its aspects meet the ecocentric principle by considering three important elements, namely economic welfare, environmental quality, and equality of equity (Joga 2013:2). Therefore, according to Joga, the aspects that must be met as a green city are green planning and design, green open space, green transportation, green building, green community, green energy, green waste, and green water as stated in the Ministry of Public Works Regulation In 2011. In addition to these eight aspects, other aspects that cannot be denied are green technology, green consumption, and green economy.

Sustainable city can be achieved if there is a balance between natural, artificial, and cultural elements that determine the quality of life of the citizens. White (2002) describes that the eco-city is "a city that provides an acceptable standard of living for its human occupants without depleting the ecosystems and biochemical cycles on which it depends". In addition to emphasizing environmental aspects, White also sees the importance of efforts to meet quality standards of life so that the concept of sustainable city here also relates to the social and economic context.

This research was conducted in two cities, Surabaya and Sidoarjo. Each city was divided into subregions that represent geographical and community characteristics. The Sub-regional division is based on several characteristics, including center of economy and government, higher education in coastal area; the economic center as well as agriculture, industrial centers, and trade centers. Similar to the division of Surabaya, Sidoarjo is also divided into based on characteristics including economic and government centers, coastal areas, agricultural centers as well as industries, economic centers, and industries. Data in this study were collected among families living in Surabaya and Sidoarjo with a total of 16 families, nine families in Surabaya and seven families in Sidoarjo. Family selection was done by random sampling so that there was no specific category to determine the characteristics of the family. In this study, researchers coach one member of each family as the 'agent' so that the practice of the Collaborative Ecoliteracy model can be monitored, analyzed and evaluated.

\section{Result and Discussion}

\section{Family-based eco-cultural literacy framework}

Itafarida et al. (2015) shows that most people in Surabaya and Sidoarjo have not fully understood the meaning of "green" in the ecocentric value of green living culture. In addition, there is a lack of 
synchronization of the practices of green living values between families and other institutions around them; even between family members. Therefore, the researcher created an ecoliteracy model called the family-based ecocultural literacy model (Figure 1).

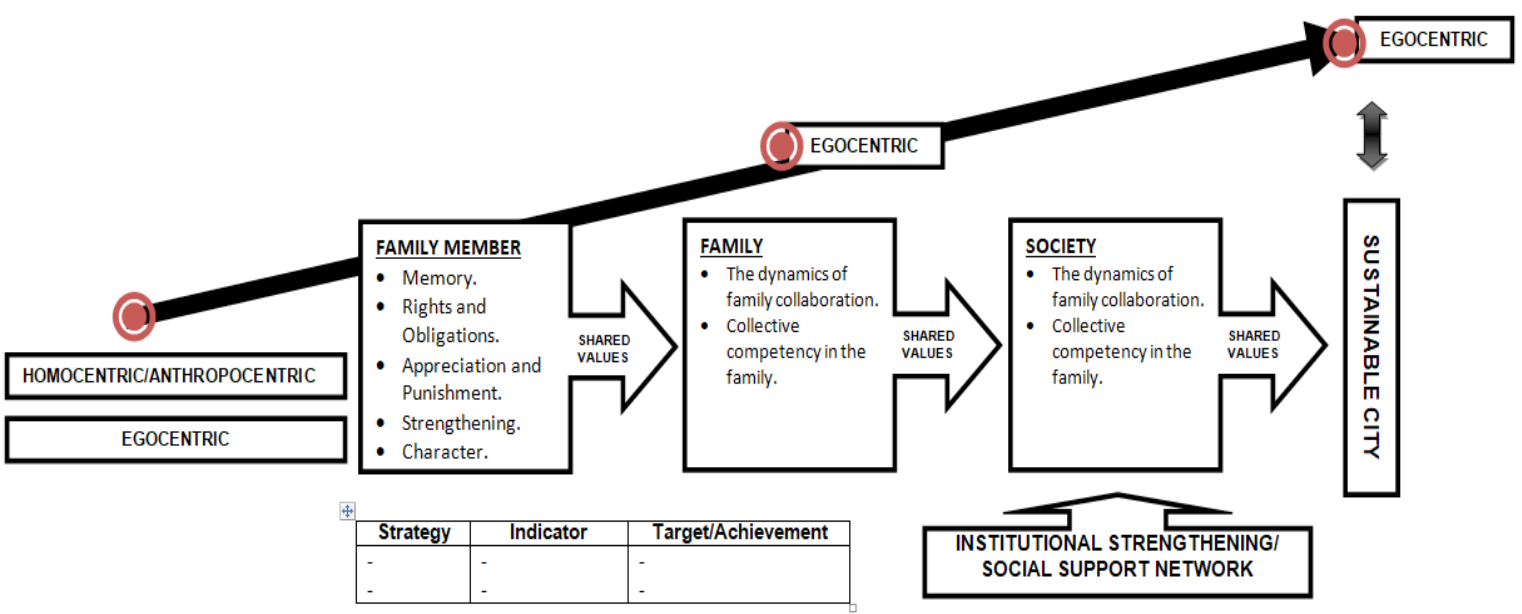

Figure 1.

Family-based eco-cultural collaborative literacy model

Source: Itafarida et al. 2016

The basis of this model is the principle of ecoliteracy, which literally means "environmental literacy". Ecoliteracy refers to the relationship between ecosystems (nature) and humans that are in harmony with the principles of the universe in harmony. The term ecoliteracy was first coined by Capra in The Hidden Connections: Integrating the Biological, Cognitive, and Social Dimensions of Life into a Science of Sustainability as "the understanding of the principles of an organization that has evolved to sustain the web of life," and is "the first step on the road to sustainability (1996:232-233). Ecoliteracy is a situation of literacy, understanding, or having an understanding of the workings of ecological principles in shared life on Earth. Ecoliteracy is a literacy strategy so that the world community can embrace and understand holism-ecological views and make necessary reforms (Capra 1996) for environmental sustainability.

This model emphasizes the changing mindset and behavior of green living in the framework of ecoculture which starts from the smallest structure in society, family. The family is seen as a proactive and consistent agent in practicing ecocentric values on family daily activities. Since it starts from the family sphere, the ecocentric values that are planted have an element of local wisdom that comes from the culture from the family as well as the modern values adopted by the family in their place of residence. In the context of ecoculture, families change their daily activities to accommodate environmental needs without ignoring the importance of environmental preservation. Changes in ecological features both locally and globally affect the daily routine activities of the family (Bernheimer et al. 1990).

The family-based eco-cultural literacy model is based on an egocentric and anthropocentric ethic or homocentric family members as part of urban communities in Surabaya and Sidoarjo. In its implementation, this model seeks to change the mindset and behavior of each family member and society from egocentric and anthropocentric or homocentric to become ecocentric. Egocentric ethics is based on individual interests that individuals have the right to use nature for their own sake, while anthropocentric or homocentric ethics are based on the assumption that "the interests of humans are higher than those of nonhumans" (Buell 2005:134). The anthropocentric or homocentric attitude is behavior based on the interests of the community that the use of nature is intended for social goals. To realize sustainable city, ecocentrism cannot be used as a reference because in anthropocentric or homocentric ethics human interests still dominate. In this model, the egocentric and anthropocentric 
or homocentric views are changed to ecocentric, where "The interest must override that of the interest of individual species" (Buell 2005:137). Ecocentric mindset and behavior are based on ecosystems or cosmos whichmeans that all things in an ecosystem have intrinsic value and deserve moral consideration.

The ecocentric perspective possessed by each individual in the family is the main capital to realize a sustainable city. Sustainable city is a city that "... enables people to meet their own needs and enhance their well-being, without degrading the natural world of other people, now or in the future" (Girardet 2004). As the Girardet statement said, it needed the cooperation of all members and elements of the community to work together to improve life together while maintaining people's lives and environmental sustainability forever. Planting ecocentric values becomes easier when it starts from the family as the smallest organizational unit in society. The infiltration of ecocentric ethics through the family allows a continuous process of supervision, habituation, and evaluation together to form shared values. Shared values or shared values are organizational values that are built by organizational leadership and adopted by other members. These values are shared and followed by all members of the organization when acting on behalf of the organization. In the model, shared values are formed gradually which starts from the scale of the individual as part of the family, as a family, and as a member of society. It has intrinsic value and deserves moral consideration.

\section{Family-based eco-cultural literacy characteristic}

The family-based eco-cultural literacy model produced in this study has six characteristics, namely bottom-up, collaborative, non-competitive, comprehensive, adaptive, and adoptive. This model will be different from existing models which usually start from government programs regarding the environment or those initiated by certain community groups or communities.

The first characteristic of the model is bottom-up. This model is purely initiated by individuals as part of urban families in response to the conditions of their urban environment that are declining quality as they experience and feel in everyday life. Therefore, this model seeks awareness of environmental sustainability that starts from individuals in the smallest social structure in society, namely the family. Thus, this family-based model considering the family as the first and foremost place of planting values.

Collaborative is the second characteristic for family-based eco-cultural literacy model. In its implementation, this model involves all individuals or family members. As a first step, in every family there are agents who monitor and evaluate green living practices to realize sustainable city so that all families have ecoliteration competencies. The selection of agents as initiators in the family is based on consideration of who interacts most with other family members and whose suggestions are considered in decision making in the family.

Furthermore, this model also has a non-competitive character. Ecoliteracy competencies are formed bottom-up and depart from the awareness of each individual to jointly strive to realize sustainable city. This model is not stemmed from certain policies or programs from regional or city governments that are in competition. With the characteristics of bottom-up, ecocentric awareness is formed naturally and is practiced continuously and supported by all family members so that it is more sustainable because it becomes part of individual character.

The fourth characteristic is comprehensive. This model is comprehensive emphasising cultural aspects to form character and ecoliteration competencies. Every family has a different cultural background. This cultural diversity makes every family maintain unique local wisdom related to the value and practice of green living culture. Apart from that, every family is also faced with urban conditions that are similar to the values and practices of green living that tend to be modern due to technological advances. In this model, elements of local and modern wisdom that support the realization of sustainable city can work together.

Furthermore, the fifth feature of the family-based ecoculture literacy model is adaptive. This model can be practiced in all regional typologies. The Surabaya and Sidoarjo sub-regions have different 
characteristics, ranging from typical industry, commercial, to agricultural. Adaptif here means that this model is not exclusive only to certain environmental conditions and typologies, but it is dynamic in accordance with the characteristics of the area of residence. This is in line with the principle of ecoculture where each family is able to be flexible towards the dynamics of the surrounding environment but still prioritizes the preservation of nature.

Finally, this model has adoptive characteristics, which can be applied to all types of family based on different or multicultural social and cultural classes. The aspects of green living to realize sustainable city practiced in the model can be done by all groups from various backgrounds. Thus, the adoptive principle is also in line with the principle of ecoculture.

\section{Implementation strategy of family-based eco-cultural literacy toward sustainable city}

Model implementation strategy is divided into two parts that of the individual level as part of family members and at the level family unit. This division becomes generally found that an egocentric perspective as an individual and an anthropocentric perspective as part of a community member dominate over an ecocentric perspective.

\section{Individual}

At the individual level, the model strategy is carried out through five stages including 1) memory; 2) rights and obligations; 3) awards and sanctions (reward and punishment); 4) reinforcement (Enforcement); and 5) characters. The five stages are a process that begins with activating insights or knowledge about the area of their settlement which is then followed up by continuous actions to be able to form an ecocentric character. In strategy of implementing the model, memory becomes the first and foremost stage to realize a sustainable city. At this stage, each individual or family member is given insight into the conditions, typology, and characteristics of the region, for example the agricultural, industrial, coastal and so on areas with various ecological characteristics. This is intended so that the practice of aspects of the green city can run in harmony and harmony so that environmental sustainability is maintained.

Furthermore, at the stage of rights and obligations, each individual is given a knowledge about what should do and what should not do to maximize environmental sustainability potential according to the typology and characteristics of the sub-region. At this stage, each family member is expected to be able to carry out the rights and obligations of the family, society and environment (human and non-human) in a public and private sphere in a balanced manner while still prioritizing environmental sustainability. For the third stage, namely rewards and sanctions (reward and punishment), the main focus is on daily practice by paying attention to the consistency of behavior in the private and public spheres. At this stage the consequences are in the form of rewards for behavior that supports ecological sustainability and sanctions for behavior that ignores ecological interests.

In the fourth stage, which is an enforcement, each family member is accustomed to practicing mindset and behavior that is environmentally friendly and supports the realization of a sustainable city continuously. In the last stage, each individual is expected to have an ecocentric character by practicing ecocentric behavior that is environmentally friendly in daily life continuously. In this case, there is a consistency of mindset and ecocentric behavior in the private and public domains; not just a culture of shame.

\section{Family}

At the family level, the model strategy is implemented through 1) family collaboration dynamics; and 2) collective competence in the family. The dynamics of family collaboration are seen in terms of collaboration between all family members to practice ecocentric mindset and behavior. Whereas family collective competence is achieved if all family members are able to transmit ecocentric mindset and behavior to the wider community. 
Aspects, indicators, and targets for the achievement of family-based eco-cultural literacy models

Aspects in this model were adopted from the aspect of the green city issued by the Ministry of Public Works and several other aspects adopted from various cities in the world that have regulations regarding sustainable cities. For indicators of achievement and achievement targets, researchers include indicators and minimum achievement targets for every aspect of a green and sustainable city that can be relatively implemented by multicultural urban communities with diverse economic levels. In the future, indicators and achievement targets can be developed accroding to the ecocentric character of the community that has been achieved. Table 1 is a minimum of aspects, indicators, and targets from the Family-Based Collaborative Ecoliteracy model:

Table 1.

Aspects, indicators, and targets for the achievement of family-based eco-cultural literacy models

\begin{tabular}{|c|c|}
\hline Aspects & Indicator and Main Achievement Target \\
\hline $\begin{array}{l}\text { Green Planning } \\
\text { and Design }\end{array}$ & $\begin{array}{l}\text { a. Land Composition } 30: 70 \\
\text { b. Sufficient air and light ventilation } \\
\text { c. Bright coloured building }\end{array}$ \\
\hline Green Open Space & $\begin{array}{l}\text { a. Having Greenery Space } \\
\text { b. Having sufficient cooler trees }\end{array}$ \\
\hline $\begin{array}{l}\text { Green } \\
\text { Transportation }\end{array}$ & $\begin{array}{l}\text { a. Walking to the surrounding place } \\
\text { b. Cycling to the midway place/using a pedicab } \\
\text { c. Motoring or using a car to the far places }\end{array}$ \\
\hline Green Building & a. Recycling building materials \\
\hline Green Community & a. Participting in cleaning, planting and securing environment \\
\hline Green Energy & $\begin{array}{l}\text { a. Efficient use of electricity } \\
\text { b. Efficient use of fuel } \\
\text { c. Efficient use of household gas }\end{array}$ \\
\hline Green Waste & $\begin{array}{l}\text { a. Managing waste by placing to the bin, Sorting out the recyclable, } \\
\text { practicing } 4 \mathrm{R} \text { (Reduce, Reuse, Recycle, and Replace }\end{array}$ \\
\hline Green Water & $\begin{array}{l}\text { a. Saving air } \\
\text { b. Creating biopori } \\
\text { c. Practicing } 3 R \text { principles }\end{array}$ \\
\hline $\begin{array}{l}\text { Green } \\
\text { Technology }\end{array}$ & $\begin{array}{l}\text { a. Using low energy household stuffs } \\
\text { b. Using LED } \\
\text { c. Efficient in using electronic stufss } \\
\text { d. Eco-driving } \\
\text { e. Consuming green-labelled products } \\
\text { f. Using alternative energy }\end{array}$ \\
\hline $\begin{array}{c}\text { Green } \\
\text { Consumption }\end{array}$ & $\begin{array}{l}\text { a. Minimize food remains and waste } \\
\text { b. Processing efficient food }\end{array}$ \\
\hline Green Economy & $\begin{array}{l}\text { a. Considering the closest production and consumption } \\
\text { b. Promote the use of local resources }\end{array}$ \\
\hline
\end{tabular}

Implementation and dynamics of collaborative eco-cultural literay in the family

This model has been implemented in 16 families in Surabaya and Sidoarjo, in 2017. The result, according to Itafarida et al. (2017) shows that the outlook for green living for each generation varies for every aspect. Of the three generations the attitude and perspective of the oldest generation - from three generations; the grandparents in the family observed in this study are still centered on how their attitudes and behavior do not harm the people around or anthropocentric. On the other hand, for some aspects such as green consumption, green waste, and green water they are relatively ecocentric. For the second generation, the consideration tends to take into account the profit-loss, for example for the green energy aspect, instead of saving the earth, the main reason for 'saving energy' is more financial considerations so that it is not wasteful. While the viewpoint of children as the third generation 
can be said to be anthropocentric because when at home parents become a role model for them. Moreover, most of the parents or second generation of the families studied were working parents so that the children did not get an understanding of the practices of green living from their parents; but they get that knowledge from their school.

Generally, the dynamics in the formation of collaborative ecoliterations have taken place. This is inseparable from the influence of agents who become important people in these families. The results of this study support several previous studies such as (Slarp 2014) and (Kim et al. 2017). Slarp (2014: ii) found that the role of people who have understanding related to the concept of green living can have a significant influence in influencing people understanding relating to this knowlegde. Furthermore, Kim et al. (2017:1) shows that there is effectiveness in the use of proverbs related to nature in increasing students' understanding of the concept of green living. This is done by the teacher as the information center for the students.

Furthermore, the roles of agents discussed previously have a significant impact in giving changes to the views and behavior of each family member. In this case, the use of these agents can already be seen as one of the effective ways to form collaborative ecoliteration based family. This can be successful because the appointed agent is a member of the family itself where the agent is involved emotionally and psychologically so that when other family members are reminded by the agent they will be well received.

\section{Collective model competency achievement}

Collective competency that has been achieved from the Collaborative Ecoliteracy model in the family that is practiced by each family in this study was formed when each of the members had begun to have the same understanding in the green living concept so that a system of cooperation between each individual occurred in the family to realize important aspects in the concept of green living into their daily actions and behavior.

Some aspects that are manifested in this family-based collective competence are aspects of green waste, green technology, green consumption and green economy. In the aspect of green waste, the collective competence that is formed is the awareness of each family member in sorting out waste between dry and wet ones, and utilizing the remaining non-organic waste, such as plastic food or beverages that can be increased by making economic value of domestic products. In addition, utilizing organic and food waste to be processed in an anaerobic composter can then be used as plant fertilizer. These things can also be defined as collective competencies where there is cooperation between each family member in practicing green living.

In the aspect of green technology, many family members who became informants in this study also practiced green living by cooperating with each other in reminding and shutting down the use of electronic goods that are no longer used or by reducing the use of air conditioners during the day and utilizing air vents that there in looking for fresh air in their homes. The application of punishment and reward is also applied by several families. This is considered to be more effective because it can increase individual awareness in practicing the concept of green living in their daily lives. In addition, the use of LED technology by several families can save energy. This was done by them because it was felt to be far more economical and the light produced through LED technology did not hurt the eyes. In this case, the role of agents in each family is important because through them other family members can learn about important aspects of implementing green living.

In terms of green consumption and economy, the collective competence shown by families in this study is realized by using local products and resources such as vegetables and fruits as their daily food intake. There are some families who also reduce the purchase of food ingredients in the modern market and prefer to buy food ingredients in traditional sellers which are much closer to them. The use of green label products is also carried out by several families because it is felt to be far more effective and efficient. For example, the use of shopping bags bearing the green label logo is used 
as a place to buy some of their daily needs. According to some family members, they felt they did not need to use plastic bags which they said had a fatal impact on the environment because it could disrupt the balance of nature.

In general, collective competencies have been formed in each of the families studied. Most of the members of each family began to try to practice the principles of green living into their lives even though they were still trapped in understanding anthropocentrism in doing these things. However, if this is done intensely, it is not impossible to understand the anthropocentrism that previously dominated the reasons why each of the family members practicing green living can turn to understanding ecocentrism.

\section{Conclusion}

Programs implemented in both cities have involved the community; but it is still found to be unsynchronized with their behavior on an individual and family scale. In addition, it turns out that government programs also have not touched the individual scale. For this reason, a strategy is needed to maximize the role of individuals and families to support Surabaya and Sidoarjo as sustainable cities.

Based on the orientation of the green living cultural values in the eleven components of a sustainable green city, it can be concluded that basically all green city programs carried out by the government are intended to realize both Surabaya and Sidoarjo as sustainable cities. Even though green city policies and programs do not cover all components, all existing policies and programs should have an ecocentric value orientation to reduce the orientation of egocentric and anthropocentric/homocentric values of individuals. The family-based ecoculture literacy model can be one of the fundamental efforts to change the perspective of each individual from being egocentric and anthropocentric to being ecocentric so that sustainable city can be realized.

\section{References}

Bernheimer LP, Gallimore R, \& Weisner TS (1990) Ecocultural theory as a context for the individual family service plan. Journal of Early Intervention 14 (3):219-233.

Berkowitz AR (1997) Defining Environmental Literacy: A Call for Action. Bulletin of the Ecological Society of America 78:170-172.

Berkowitz AR, Ford ME, \& Brewer CA (2005) A Framework for Integrating Ecological Literacy, Civics Literacy, and Environmental Citizenship in Environmental Education, 227-265. In: EA Johnson \& MJ Mappin (eds). Environmental Education or Advocacy: Perspectives of Ecology and Education in Environmental Education. Cambridge University Press, New York, New York, USA.

Buell L (2005) The Future of Environmental Criticism: Environmental Crisis and Literary Imagination. USA: Blackwell Publishing.

Capra F (1996) The Web of Life: A New Scientific Understanding of Living Systems. New York: Doubleday.

Coupe L (2000) The Green Studies Reader: From Romanticism to Ecocriticism. New York: Routledge.

Girardet H (2004) Cities People Planet: Liveable Cities for a Sustainable World. John Wiley and Sons.

Itafarida S (2014) Membangun eco city melalui pemanfaatan nilai budaya green living masyarakat urban yang multikultural di pemukiman Surabaya dan Sidoarjo, jawa timur. Unpublished.

Itafarida S (2015) Strategi pengembangan nilai budaya green living masyarakat urban di pemukiman Surabaya dan Sidoarjo untuk mewujudkan sustainable cities. Unpublished.

Itafarida S (2016) Strategi pengembangan nilai budaya green living masyarakat urban di pemukiman surabaya dan sidoarjo untuk mewujudkan sustainable cities. Unpublished.

Itafarida S (2017) Penguatan infrastruktur sosial dan budaya masyarakat surabaya dan sidoarjo untuk mewujudkan sustainable cities. Unpublished. 
Joga N (2013) Gerakan Kota Hijau. Jakarta: PT Gramedia.

Kim GW, Vaswani RT, Kang W, Nam M, \& Lee D (2017) Enhancing ecoliteracy through traditional ecological knowledge in proverbs. Sustainability 9 (1182):1-16.

Leger MT \& Pruneau D (2011) A grounded theory perspective on eco-sustainable change in families. Ecopsychology 3 (4):237-247.

McBride BB, Brewer CA, Berkowitz AR, \& Borrie B (2013) Environmental literacy, ecological literacy, ecoliteracy: What do we mean and how did we get here?. Ecosphere 4:1-20.

Merchant C (1990) Environmental Ethics and Political Conflict: A View from California, 45-68. In: E Hargrove (ed). Environmental Ethics. Texas: Center for Environmental Philosophy (University of North Texas).

Orr DW (1992) Ecological literacy: education and transition to a postmodern world. SUNY Press, Albany, New York, USA.

Schwartz SH (1992) Universals in the Content and Structure of Values: Theoretical Advances and Empirical Tests in 20 Countries. In: M Zanna (ed). Advances in Experimental Social Psychology. Orlando, FL: Academic Press.

Slarp M (2014) How Ecoliterate is a Five Year Old? Investigating the Effects of a Teaching Intervention on Kindergarten Children's Understanding of Ecological Concepts. Master Dissertation. Sidney: The University of Sidney.

Steward JH (1993) The Concept and Method of Cultural Ecology. New York: Irvington Publishers.

White RR (2002) Building the Ecological City. Cambridge: Woodhead Publishing Ltd. 